Article

\title{
Are-Bure-Boke
}

\section{Distortions in Late 1960s Japanese Cinema and Photography}

\author{
Marco Bohr, Loughborough University
}

IN THIS PAPER I analyse Matsumoto Toshio's film Funeral Parade of Roses (Bara no Sōretsu, 1969) in relation to emerging practices in Japanese photography of the late 1960s. ${ }^{1}$ Set in Tokyo's underground gay culture, previous discussions of Matsuomoto's iconoclastic film have concentrated on the protagonists' subversion of gender roles. Funeral Parade of Roses is widely acclaimed for being the first film to represent discourses on homosexuality in Japan. Beyond this immediate reading, however, Matsumoto's film is also deeply political and characteristic of its time. My analysis will concentrate on a key scene in which the subversion of a dominant social order is attempted by a conscious disregard of cinematic conventions. This desire to uproot conventions of representation can be observed in a 'style' of photography called are-bureboke, or 'rough, blurred, out-of-focus', popularized by Japanese photographers in the late 1960s. In this paper, I will establish that these cultural practices emerged concomitantly and that they are linked in a number of ways. Purely on a visual level, and with regard to the materiality of motion picture film stock and photographic printing techniques, Matsumoto's film shares formal and aesthetic concerns with 
are-bure-boke photography. Filmmakers and photographers also frequented the same district in Tokyo, near Shinjuku station, which was a hotspot for the New Left movement and student protests of the time. Yet, as I will argue, the most important link between Japanese cinema and photography of the late 1960s is a shared ideology based on the belief that outdated modes of representation needed to be dramatically transformed.

\section{Cinematic Distortions}

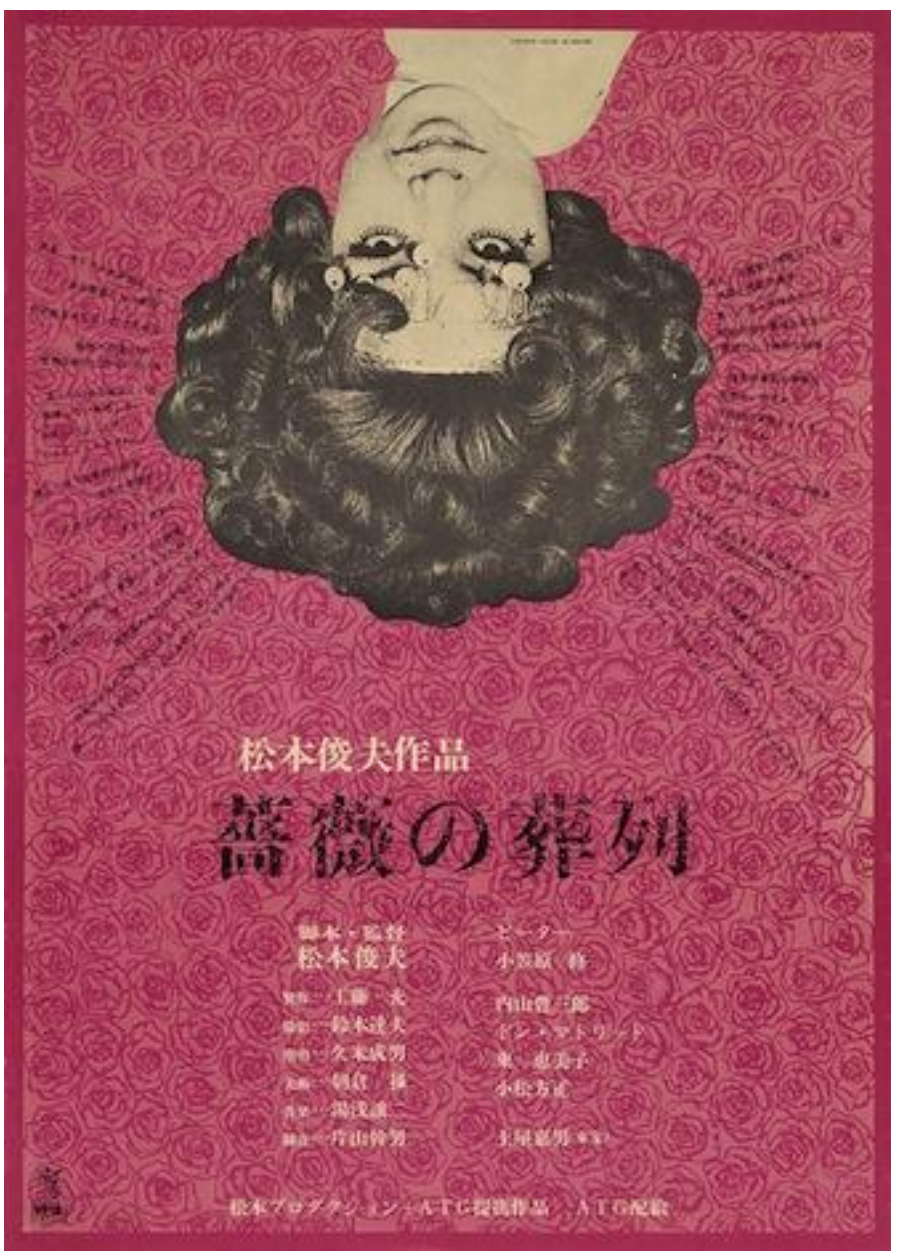

Fig. 1. Poster for Funeral Parade of Roses

Funeral Parade of Roses tends to be categorized under the Japanese New Wave, designating a group of Japanese filmmakers emerging from the late 1950s through the early 1970s. ${ }^{2}$ Because of an ideological, political, and aesthetic proximity to French Cinema produced at the time, the Japanese New Wave is at times compared to the Nouvelle Vague movement. As the film historian David Desser has pointed out, however, 'while the Japanese New Wave did draw benefits from the French New Wave, mainly in the form of a handy journalistic label which could be applied to it $[\ldots]$ it nevertheless possesses a high degree of integrity and 
specificity. ${ }^{3}$ Desser thus urges us to move away from the Orientalist paradigm of viewing the East, and Japan in particular, as a culture that copies from the West. As Edward Said has established in his iconic book Orientalism, the 'Orientalist now tries to see the Orient as an imitation West'. ${ }^{4}$ Desser's argument for the autonomy of the Japanese New Wave is important here, because it establishes a framework in which the materiality of the film itself, rather than any forced similarities to Western cinema, can be analysed in more depth.

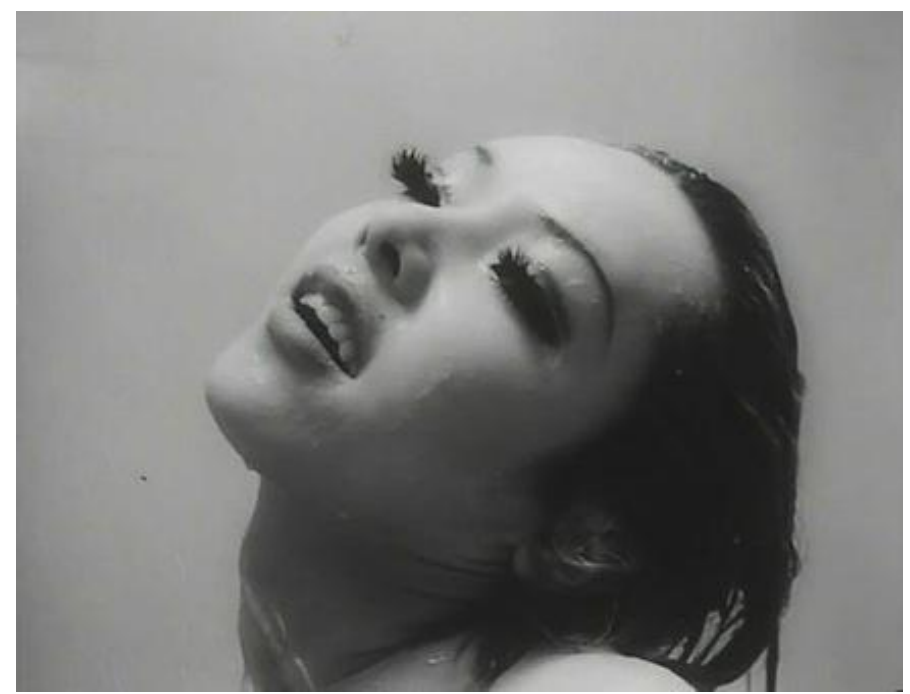

Fig. 2. Eddie in Funeral Parade of Roses

Yet even within the category of the Japanese New Wave, Funeral Parade of Roses sits uncomfortably. Funeral Parade of Roses is, in the true sense of the word, iconoclastic - a film that breaks from an established dogma. This is to a large extent due to its plot. Vaguely based on the Oedipus myth, the film concentrates on the 'gay boy' Eddie. Played by a well-known Japanese transvestite called Peter, Eddie's effeminate looks and sensuous movements create a continuous cycle of visual pleasure throughout the movie. However, just as the protagonist inverts his gender identity by cross-dressing, wearing make-up and wigs, the film also inverts the narrative of the Oedipus myth. Eddie kills his mother and has a sexual encounter with his father, who fails to recognize his son under the disguise of his transformation. As in the Greek myth, the film ends in a harrowing scene in which Eddie gouges his eyes out. Filled with homoeroticism, philosophical observations, drug consumption, performance art, and wanton violence, Funeral Parade of Roses is a tourde-force through Tokyo's underground culture. Amongst film theorists and experts on Japanese visual culture, Funeral Parade of Roses has been widely lauded as a pathbreaking work of cinema with regard to the representation of homosexuality and performed gender identity. Mark McLelland, for instance, writes that the film is about 'the right to enact femininity as a style, or even "way" of being in the world, a project to which biology has little to contribute'. 


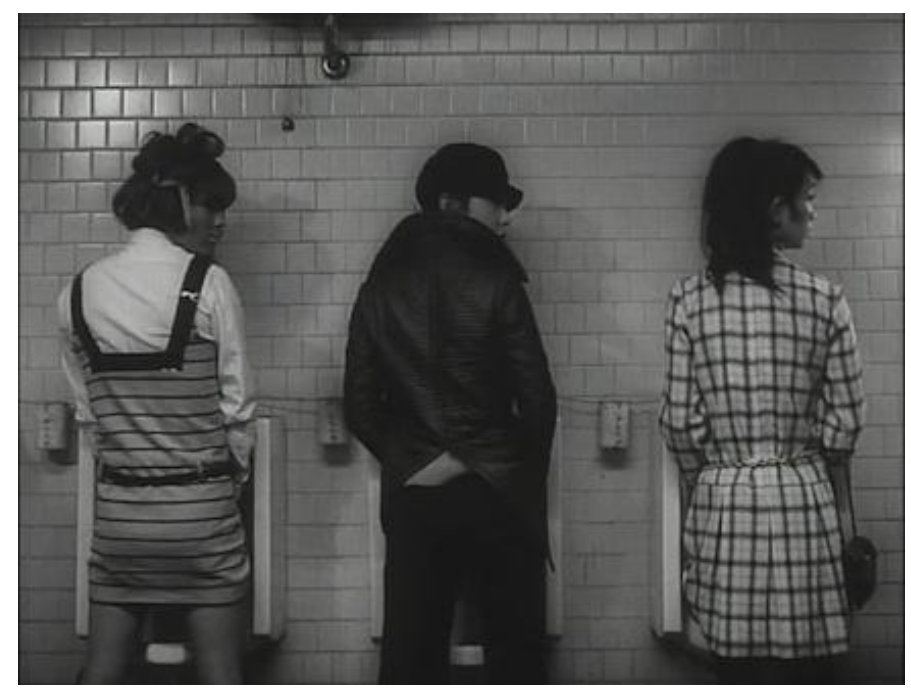

Fig. 3. Eddie and his friends in Funeral Parade of Roses

The overriding trope of homosexuality and transvestism is however only symbolic for a far wider-reaching theme in the movie. As David Desser has observed, 'ambivalence, so important in the sexual attraction of crossdressing, also functions in this film as a political category'. ${ }^{6}$ In that sense, contiguous to the agenda of the 'sexual revolution' of the late 1960s in America, cross-dressing can be read as countering a dominant hegemonic order in the Funeral Parade of Roses. Matsumoto's film signals a paradigm shift not only with regard to the narrative, but also how this narrative is cinematically represented. Here, it is important to note that before Matsumoto embarked on Funeral Parade of Roses, he was primarily a documentary and experimental filmmaker. This proximity towards experimental film is also discernable in Funeral Parade of Roses: some scenes evoke a hallucinogenic trip, interlacing still photographs of a sexual nature with in-camera effects and psychedelic music.

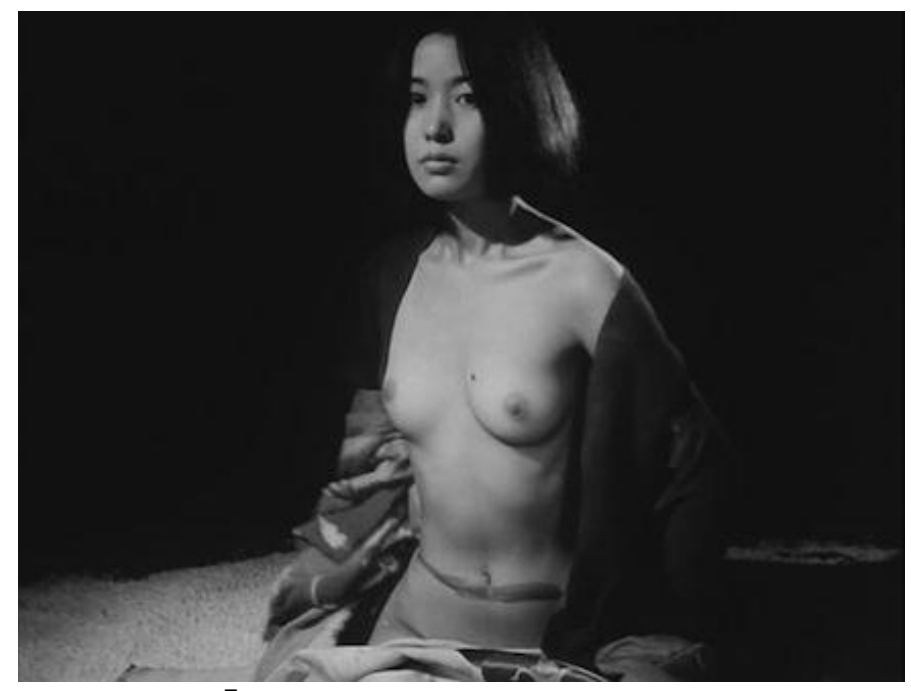

Fig. 4. Ōshima Nagisa, Diary of a Shinjuku Thief

(Shinjuku dorobō nikki), 1968. 
Even in comparison to Japanese avant-garde movies produced prior to 1969, Funeral Parade of Roses stands out. An exception is Ōshima Nagisa's Diary of a Shinjuku Thief (Shinjuku dorobō nikki, 1968). Featuring a title borrowed from the French writer Jean Genet's The Thiefs Journal (1949), the film explores the links between sexual and political radicalism, examining the day-to-day life of a would-be radical whose sexual desires take the form of kleptomania. The fragmented narrative is interrupted by commentators, including an underground performance troupe, a psychoanalyst, and an impromptu symposium featuring actors from previous Ōshima films and Ōshima himself. Similar to Funeral Parade of Roses, the dissection of shifting sexual politics, as embodied by various characters within the film, is symbolical for the political radicalism the film seeks to express. While Öshima refers to the revolutionary Genet with the title of his movie, a central scene in Funeral Parade of Roses is Bar Genet which - similar to the milk bar in Stanley Kubrick's A Clockwork Orange (1971) - signifies a type of dystopia. ${ }^{7}$

The reason why Ōshima's Diary of a Shinjuku Thief and Matsumoto's Funeral Parade of Roses were able to transgress cinematic conventions so radically can be traced to the way the films were funded. The Art Theatre Guild, or ATG, supported independent filmmakers who, in turn, presented their movies at ATG cinemas. The funding was only a fraction of that paid by major studios, and as a result, these independently funded films appear more raw, more chaotic, and more critical of the capitalist ideology the studios were a part of. While Ōshima represents the critique of a capitalist society and consumerism by the kleptomania of his main protagonist, Matsumoto's inversion of assumed gender identities can also be read as an inversion of a social order, or, in other words, of social conventions inherited by a capitalist agenda.

With regard to a rejection of cinematic orthodoxies in Funeral Parade of Roses, one scene in particular stands out. Eddie and another man walk home from a night out drinking at Bar Genet. As Eddie and his partner for the night fall to the ground in drunken laughter, two men wearing white helmets and long sticks run past them through the narrow alley. The reference here is clear: much like Paris, Berlin, Prague and Rome, Tokyo too was an urban battleground for students clashing with the police in the tumultuous years of 1968 and 1969. The white helmet, commonly supplied by Japanese universities against the omnipresent threat of an earthquake, was the signifier of the student revolt. 


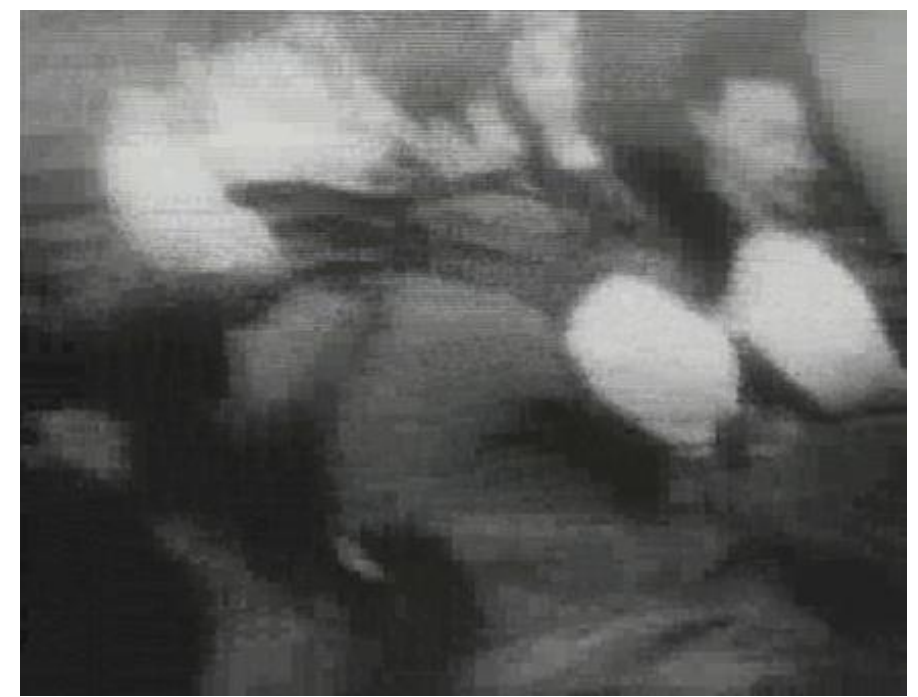

Fig. 5. Scrambled television footage in Funeral Parade of Roses.

In the next shot, some of Eddie's friends can be seen gathering around a television set emitting scrambled news footage. On closer inspection, the white helmets worn by the protestors running past Eddie a few seconds earlier in the film reappear in the television image watched by Eddie's friends. The image is extremely unclear, but it appears to show the fierce battles between the students and the police. A bearded man referred to as 'Guevara' is filming this scrambled footage with a $16 \mathrm{~mm}$ film camera. As the clarity of the transmission improves, Guevara says 'cut', in apparent disappointment that the footage has become clear. Another man gets up and bashes the television set in the hope that the image becomes scrambled again. After a few good bangs, the distortions in the footage resume and Guevara tells the cameraman to start filming the television again.

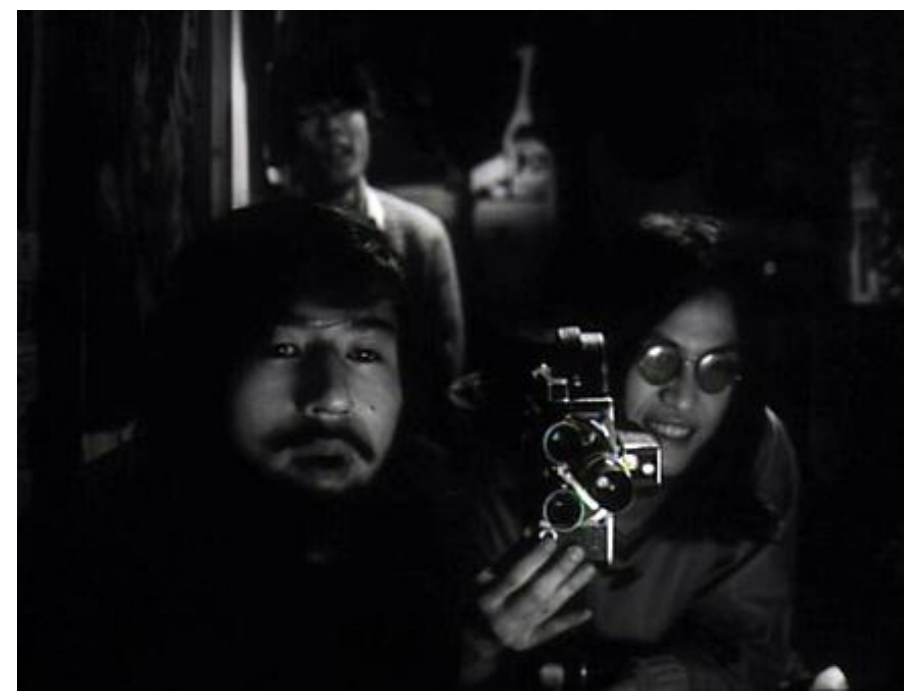

Fig. 6. Guevara and his friends filming scrambled television footage in Funeral Parade of Roses. 
Apart from pointing to the self-referentiality and inter-textuality prominent in Japanese filmmaking of the late 1960s, the filming of the television image offers a number of important interpretations. The film theorist Stephen Barber views the scene as constituting the failure by Eddie's friends for not being part of the students protests themselves. Barber writes:

The corporeal distance from the city unfolds in layer upon layer of media images that paralyse active participation in the upheavals while simultaneously inciting a sense of euphoria. The revolutionaries' elation precipitates a furore of naked dancing and then an orgy, the film images disintegrating into scrambled human forms crammed between the thin walls of their room. ${ }^{8}$

The filming of a scrambled television thus becomes the allegorical foreplay for the scrambling of bodies in the sexual orgy later in the movie.

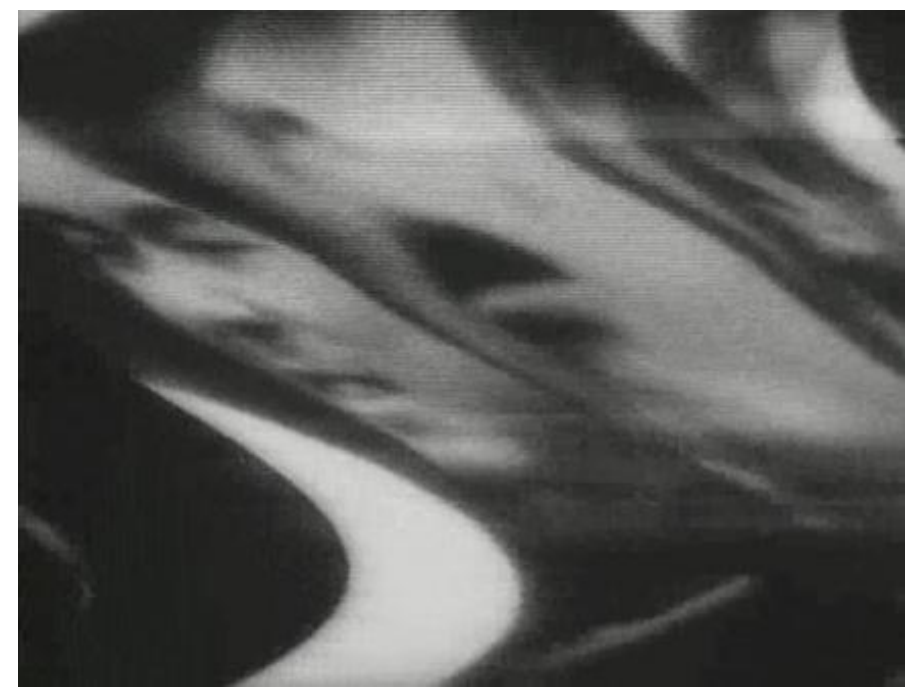

Fig. 7. Scrambled television footage in Funeral Parade of Roses.

Rather than viewing the scene as constituting the paralysis and eventual break-up of the student movement, however, the very form in which it is filmed is more radical than the protagonists' passivity might first suggest. By including a scene in which a man is filming with a $16 \mathrm{~mm}$ camera, director Matsumoto Toshio is referring to his own practice as an experimental filmmaker prior to his directorial debut of a feature-length film with Funeral Parade of Roses. The scene thus becomes a type of meta-cinema, a cinema that self-consciously addresses the devices of cinema. Here, Matsumoto also appears to tread on Brechtian techniques of 'breaking the fourth wall': while the actors do not address the camera directly, by filming a man operating a film camera, Funeral Parade of Roses draws attention to the very act of filmmaking itself. To confront the viewer with the mechanics of the filmmaking process, other 
scenes are also preceded by leader or a clapboard. The television footage scene is characteristic for the synthesis, and critique, of different visual categories: mixing news footage with narrative cinema, documentary and experimental film, Funeral Parade of Roses alludes to the apparent dissolution, or rupture, of defined cinematic genres.

The most crucial aspect in this lengthy montage is that the filmed television footage is visually scrambled and distorted. By depicting the news footage of the battles between students and the police, Matsumoto might be questioning the portrayal of these events in the media. If the original portrayal of the students' struggle by the media was already distorted to begin with, Matsumoto is aiming to distort this image even further by depicting the scrambled footage. The physical distortion of the image thus becomes a visual strategy that enables a confrontation with the 'truth' as disseminated in the news.

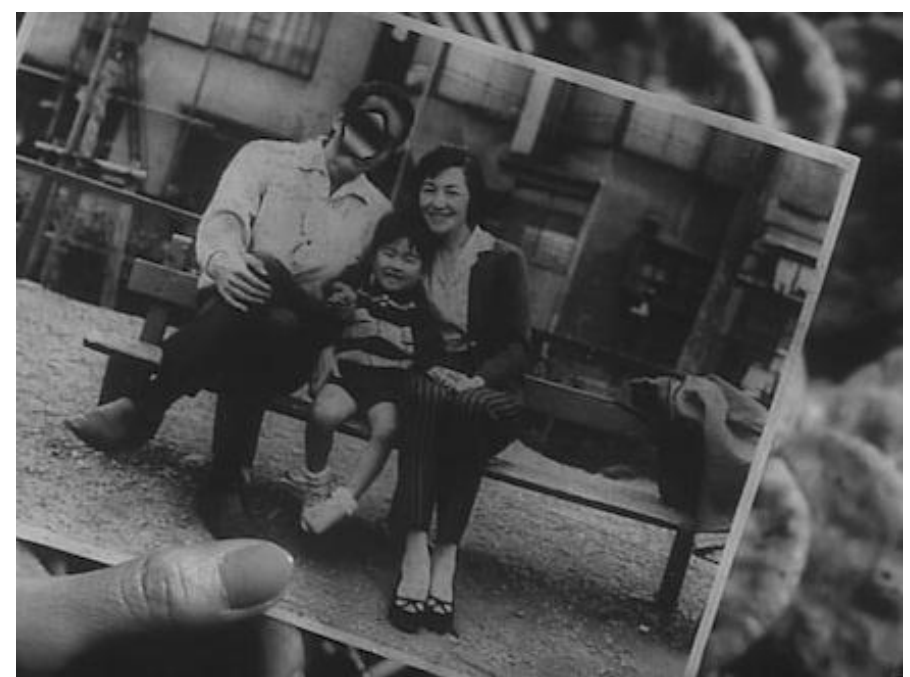

Fig. 8. Eddie burns a family photograph in Funeral Parade of Roses.

The apparent embrace of distortions in Funeral Parade of Roses might however be a reflection of a wider shift occurring with regard to visual representation at the time. In the history of modernism, cinema and photography have long been perceived as objective mediums. In particular, the humanist paradigm of photography reflecting social conditions also embraced the notion of a photographic 'truth'. Referring to the French word for lens, objectif, the French film critic André Bazin once argued for 'the essentially objective character of photography'. 9 The lens of a film camera thus lends the medium of cinema an aura of objectivity following this linguistic slippage. Similarly, the etymology of the Japanese word for photography, shashin, presupposes that photography is capable of 'copying the truth'. By blurring the distinction between the subjective and objective in Funeral Parade of Roses, Matsumoto breaks from the 'essentially objective character' ascribed to cinema and photography. In another crucial scene, and in line with the troubled relationship between father and son, Eddie burns the face of his 
father in a family photograph. While this scene can be read in conjunction with the complexities of Freud's notion of the Oedipus complex, I believe the burning of the photograph is more indicative for what Matsumoto has set out to do throughout the whole movie: an allout attack on all modes of representation, film, television, and here, also photography.

\section{Photographic Distortions}

In the late 1960s, a key location for aspiring photographers was the Shinjuku district in Tokyo, the very same area where Funeral Parade of Roses and also Diary of a Shinjuku Thief were filmed. Shinjuku was synonymous with rapid urban growth, newly-built high-rises, the signifiers of a burgeoning capitalist society, while on the other hand it also had a vast red light district which allowed for transgressive behaviour. In addition, it was the central location for the student protests and the ensuing battles with the police in the late 1960s. The contrast between student revolt, sexual hedonism, and the aspirations of post-war Japan made for rich material for photographers and filmmakers. In fact, owing to the topographical, ideological, and political affinities of imagemakers at the time, photographers and filmmakers often collaborated. On 5 January 1969, the well-known photographer Moriyama Daidō took a series of photographs on the set of Funeral Parade of Roses, which was, at the time, still in production. ${ }^{10}$ Later that same year, Moriyama appears to have liberally borrowed from the film's scrambled television footage scene. Photographing for his famous 'Accident' series for the magazine Asahi Camera, Moriyama photographed television news coverage of a kidnap murder case. ${ }^{11}$ Like in Funeral Parade of Roses, the television image was scrambled.

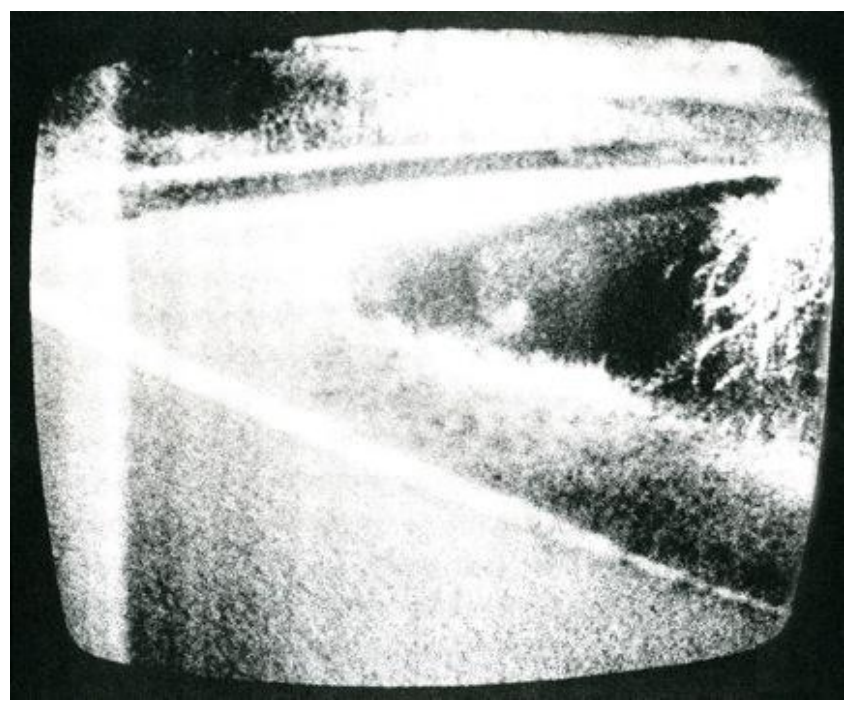

Fig. 9. Moriyama Daidō, Accident 11, first published in Asahi Camera, November 1969. 
The embrace of a blurred image in Funeral Parade of Roses is of particular importance because this blurring of visuality was one of the main constituents of a new development emerging among Japanese photographers at the time. Moriyama in particular is often brought up in connection with visually distorted images. The photography critic Yamagishi Shōji once wrote that Moriyama "has come to be called "a standard bearer of the blurred image". ${ }^{22}$ For most historians of photography, a cataclysmic moment in the rise of this form of photographic expression was the inception of the quarterly magazine Provoke in November 1968, self-published by a consortium made up of the photographers Nakahira Takuma, Takanashi Yutaka, the critic Taki Kōji, and the poet Okada Takahiko. ${ }^{13}$ The photographers associated with Provoke, among whom, again, is Moriyama Daidō (despite only joining during the second issue), are widely regarded in the history of Japanese photography. The art historian Rika Iezumi Hiro succinctly summarizes that

the 'grainy, blurry, out-of-focus' style emblematic of Provoke's photography, particularly Moriyama's, is best suited to portray the psychological reality and uncanny feeling about one's existence in a modern city that is mired and destabilized by political disturbances (such as student riots), expanding consumer culture, and the society of the spectacle. ${ }^{14}$

Although Provoke only lasted for three issues until 1969, the radical attitude towards representation instigated, or rather, provoked, a golden age for photographic discourses in Japan. The late 1960s are regarded as a time when photographic expression underwent a dramatic shift: away from photographic 'objectivity' or 'truths', to a far more subjective and radical attitude towards the medium. In the first issue, the Provoke group write in what can now only be interpreted as a manifesto:

At a time when language has lost its material base, its reality, and is simply dancing in space, what falls to us photographers must be to capture with our own eyes the shards of reality that existing language cannot possibly grasp, and to aggressively confront language and confront thought with a variety of data. ${ }^{15}$

The call to 'confront' language and thought is highly suggestive of the student battles carried out in that eventful year of 1968. The target of this confrontation, one can only speculate, were possibly the newspapers that galvanized public opinion and demonized the actions of leftist student groups. The timing of Provoke's inception is also important. Provoke was launched in November 1968, only days after one of the biggest and most brutal battles between the police and rioting students at the International Anti-War Day, 21 October 1968. But there is another section in the above paragraph that requires further attention: 'language 
has lost its material base, its reality, and is simply dancing in space'. At a closer look, these words are likely a veiled reference to the Communist Manifesto, in which Karl Marx famously wrote 'all that is solid melts into air, all that is holy is profaned, and men at last are forced to face with sober senses the real conditions of their lives and their relations with their fellow men'. Yet as opposed to addressing their 'fellow men', the Provoke group referred more exclusively to fellow photographers, which seems unusual since they sought to confront language and thought not only with photographs, but with 'a variety of data'. Despite this apparent contradiction, one can sense in the Provoke manifesto an ensuing moment of crisis, yet also a desire for a new beginning - not only for photography, but for other modes of representation too. ${ }^{16}$

Here, the Provoke group's desire to radically change assumed orthodoxies also seems to mirror an ideological shift in the West. In 1969, Paul de Man wrote that 'the full power of the idea of modernity' lay in a 'desire to wipe out whatever came earlier', so as to achieve 'a radically new departure, a point that could be a true present'. ${ }^{17}$ In the case of Japan, however, such a desire to wipe out the past seems particularly fraught with difficulty considering the heavy burden of Japan's history as aggressor and victim of aggression during WWII. The American presence in Japan was one of the focal points of the student protests in the late 1960s. The Provoke group's position on America's militaristic, political, and cultural colonization of Japan can be best distilled from photographs by Moriyama, who went to photograph American products sold in supermarkets located in Aoyama, the district of Tokyo that is home to the US military Japan headquarters and where American consumer goods could be, and still can be, found most readily. While a more general critique of capitalism could be argued for here, Moriyama's crude photographs of American branded goods such as Hershey chocolates are more specifically a representation of what Marx has called a fetishism of the commodity. In this work, one can also discern a criticism against cultural imperialism, yet as Moriyama has also quite liberally copied from Andy Warhol in his photographs of Campbell's soup cans, this critique is problematized by having chosen to mimetically respond to an artist who has himself thrived on the perception of art as fetish. Another one of the great ironies with regard to Provoke is that the magazine itself became a highly fetishized commodity in its own right. Despite, or maybe precisely because it lasted only for a total of three issues, it has reached a legendary status among photographic connoisseurs: the online retailer AbeBooks currently lists the three issues at a staggering 22,000 US Dollars. ${ }^{18}$ 


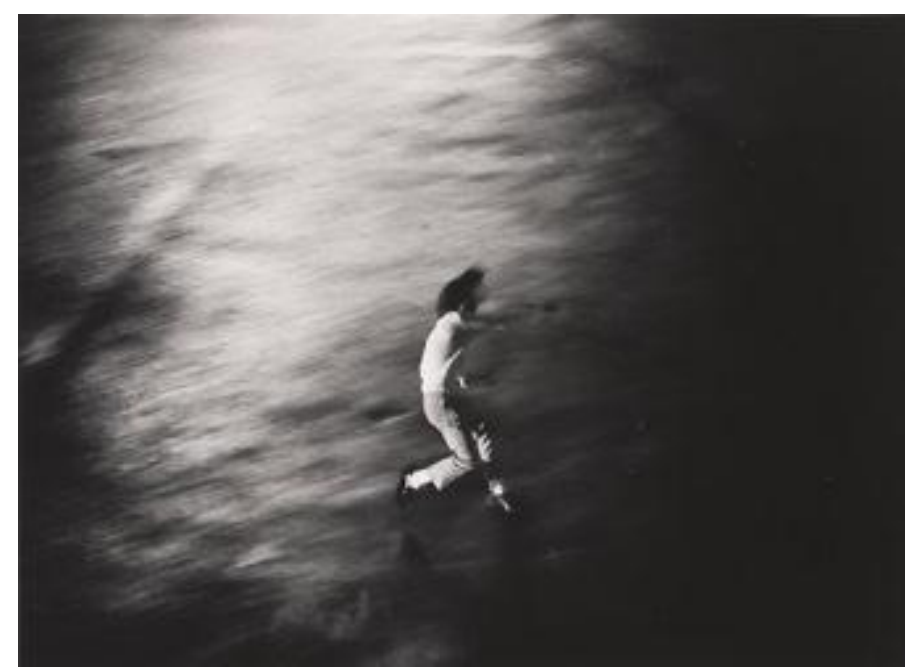

Fig. 10. Tōmatsu Shōmei, Untitled, from the series Protest, Tokyo, 1969.

The insistence that the Provoke group developed the photographic style are-bure-boke, then, fails to recognize that this form of photographic representation was also a reflection of the political turmoil. Other photographers, ones that weren't necessarily part of the Provoke group, also utilized a rough and raw form of photographic representation at the time. The veteran photographer Tōmatsu Shōmei, for instance, began to embrace a form of photographic expression that thrived on subjectivity and abstraction. One of Tōmatsu's best-known photographs depicts the student protests in 1969: here too, blurriness is an integral part of the photograph. A man is in forward motion, his body propelled by the velocity of his movements; he appears to be hurling an object, a stone, perhaps. The photograph seems to be taken in low light conditions, forcing the photographer to reduce the shutter speed. By training the camera on the man in motion, rather than his surroundings, the man ends up more or less in focus, whereas everything around him is blurred. The photograph gives the appearance that the man is floating in space, his white socks and black leather shoes standing in contrast to his actions. As blurriness is such an integral part of the photograph, Tōmatsu is also blurring the line of the medium of photography itself. After all, we are looking at a still photograph that is representing movement. As with Matsumoto in Funeral Parade of Roses, here we have another imagemaker who seeks to push the boundaries of his chosen medium. While Matsumoto included still photographs and news footage in his film, Tōmatsu, on the other hand, seems to apply the cinematic panning shot to his photographs. The blurring of the image is a visual metaphor for the blurring between the categories of the still and the moving image.

As Ivan Vartanian and the eminent photography historian Kaneko Ryuichi have shown in their illustrated book Japanese Photobooks of the 1960s and '70s, university photography clubs such as from Nihon Daigaku also applied the techniques of visually distorting their photographs. Vartanian and Kaneko point out that 'students accidentally achieved the 
same effects that [...] Moriyama Daidō deliberately pursued with [his] are-bure-boke (grainy, blurry, out-of-focus) photography,. ${ }^{19}$ So while the visual distortions were 'accidental' for the students, they were 'deliberate' for the emerging masters of photography. The photographic conditions under which students and photographers operated were however very similar, if not the same. As the art historian T. J. Clark has urged:

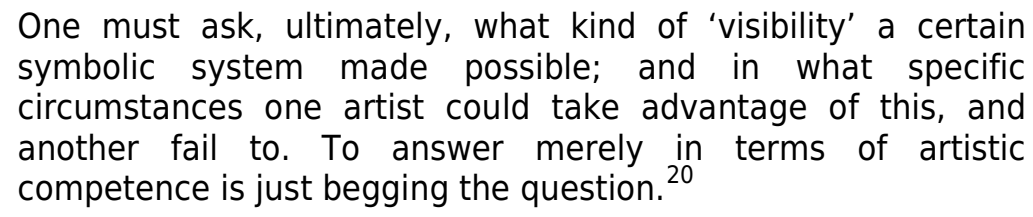

The specific circumstances that led to the emergence of visually distorted photographs is not so much related to the artistic competence of the photographers as to the subject that was being photographed. The protests taking place in Tokyo's dense urban landscape required a quickhanded approach to photography, operating under low light conditions and fast-changing events. The blurring of photographs depicting the student protests also had a practical element: the photographs could not later be used to identify certain protesters. As I hope to have shown, this shift occurred not solely among the photographers associated with Provoke, but rather encapsulated a large variety of image-makers, from Tōmatsu Shōmei to the photography students at Nihon University. My point is that the visual distortions appearing in Japanese photography of the late 1960s cannot simply be reduced to a creative decision made by a selected and elite bunch of photographers associated with Provoke. Their photographs represent a social order that is far greater than their individual circumstances suggest. Distortions in Japanese photography of the late 1960s do not merely represent a 'style', but rather these distortions are representative of a generation coming to terms with what they viewed as an economic, political, and social system that was itself distorted.

\section{Conclusion}

We have two parallel developments occurring in Japanese visual culture. In cinematic discourse, films like Funeral Parade of Roses break away from cinematic traditions by embracing visual distortions with meta-cinematic techniques, while in photographic discourse, a similar movement towards subjectivity and abstraction seeks to disturb the modernist paradigm of a photographic truth. Both the filmmakers and photographers discussed in this essay are testing new boundaries in their chosen mediums, and by doing so, a convergence between cinema and photography is taking place. Not only did photographers and filmmakers borrow techniques from each other, filmmakers also inserted actual photographs into films while photographers adapted the cinematic 
panning shot. Japanese cinema and photography of the late 1960s is characterized by its hybrid forms, but also by a desire to push the boundaries of what is technically possible. The cinematic and photographic transformations have numerous points of convergence. They share the topographical specificity of being centred in Tokyo (and the Shinjuku district in particular), they share an embrace with the blurry, the grainy, and the out-of-focus, but above all, not least due to the subject matter, the cinematic and photographic transformation emerges out of a revolutionary desire to uproot any kind of tradition of representation. The distortions in late 1960s Japanese cinema and photography signify the vivacity of political protest, ideological turf wars, and sexual empowerment of a generation, and signify a new form of subjective, fluid, even, unresolved mode of representation.

\section{Loughborough University}

\section{Notes}

\footnotetext{
${ }^{1}$ In this paper, Japanese personal names are listed in the traditional order: last name first, followed by given name. Exceptions are applied to those who publish in the English language, such as Rika Iezumi Hiro.

${ }^{2}$ David Desser, Eros Plus Massacre: An Introduction to the Japanese New Wave Cinema

(Bloomington, IN: Indiana University Press, 1988), p. 96.

${ }^{3}$ Desser, Eros Plus Massacre, p. 4.

${ }^{4}$ Edward Said, Orientalism (London: Penguin, 1978), p. 321.

${ }^{5}$ Mark McLelland, 'Japan's Original "Gay Boom”, in Popular Culture and Globalization in Japan, ed. by Matthew Allen and Rumi Sakamoto (London: Routledge, 2006), p. 169.

${ }^{6}$ Desser, Eros Plus Massacre, p. 96.

${ }^{7}$ Movie blogs and websites have pointed to a number of similarities between Funeral Parade of Roses (1969) and A Clockwork Orange (1971): like Eddie, A Clockwork Orange's main protagonist Alex wears make-up, albeit only on one eye. Similar to a scene in Funeral Parade of Roses where Eddie and his friends start a street fight with some girls in Tokyo, Alex's gang in A Clockwork Orange also engage in outbursts of violence in the streets of London. Psychedelic music, the fast forwarding of movie footage, and the inclusion of other visual elements that contravene cinematic conventions, raises the possibility that Stanley Kubrick directly borrowed from Funeral Parade of Roses.

${ }^{8}$ Stephen Barber, Projected Cities: Cinema and Urban Space (London: Reaktion, 2002), p. 142.

${ }^{9}$ André Bazin, 'The Ontology of the Photographic Image' [1967], in Classic Essays on Photography, ed. by Alan Trachtenberg (New Haven, CT: Leete's Island, 1980), p. 241.

${ }^{10}$ Daidō Moriyama, 1965-1970 Nippon Gekijyō [Japan Theatre] (Tokyo: Getsuyosha. 2009), pp. 201-07.

${ }^{11}$ Moriyama, 1965-1970 Nippon Gekijyō, pp. 345-51.

${ }^{12}$ Shōji Yamagishi, A Hunter by Daido Moriyama (Tokyo: Chūō-kōron-sha, 1972), not paginated.

${ }^{13}$ Kōtaro Iizawa, 'The Evolution of Postwar Photography', in The History of Japanese Photography, ed. by Anne Wilkes Tucker and others (New Haven, CT: Yale University Press, 2003).

${ }^{14}$ Rika Iezumi Hiro, 'Between Absence and Presence: Exploring Video Earth's What is Photography?’ Invisible Culture, 15 (2010), pp. 79-101 (pp. 94-95).

${ }^{15}$ Kōtaro Iizawa, 'The Evolution of Postwar Photography', in The History of Japanese Photography, ed. by Anne Wilkes Tucker and others (New Haven, CT: Yale University Press, 2003).

${ }^{16}$ An intriguing parallel can be observed in the manga magazine Com, which was launched by Tezuka Osamu in 1967. The first issue, in a very similar tone to that of Provoke, starts with this founding statement spiked with Marxist terminology: 'It is said that now is the golden age of manga. So shouldn't works of outstanding quality be published? Or isn't the real situation one in which many manga artists are being worked to death, while they are forced into submission, servitude and cooperation with the cruel requirements of commercialism? With this magazine I
} 
thought I would show you what real story manga is. Com is a magazine for comrades who love manga.' Quoted in Sharon Kinsella, Adult Manga: Culture and Power in Contemporary Japanese Society (London: Routledge. 2000), p. 103.

${ }^{17}$ Quoted in Marshall Berman, All That is Solid Melts into Air: The Experience of Modernity (London: Penguin, 1987), p. 331.

${ }_{18}^{18}$ AbeBooks <http://www.abebooks.com/> [accessed 9 May 2011].

${ }^{19}$ Ivan Vartanian and Kaneko Ryuichi, Japanese Photobooks of the 1960s and '70s (New York: Aperture Foundation, 2009), p. 146.

${ }^{20}$ T. J. Clark, Image of the People: Gustave Courbet and the 1848 Revolution (London: Thames and Hudson, 1988), pp. 16-17.

\section{Works Cited}

Barber, Stephen, Projected Cities: Cinema and Urban Space (London: Reaktion, 2002)

Bazin, André, 'The Ontology of the Photographic Image' [1967], in Classic Essays on Photography, ed. by Alan Trachtenberg (New Haven, CT: Leete's Island, 1980)

Berman, Marshall, All That is Solid Melts into Air: The Experience of Modernity (London: Penguin, 1987)

Clark, T. J., Image of the People: Gustave Courbet and the 1848 Revolution (London: Thames and Hudson, 1988)

Desser, David, Eros Plus Massacre: An Introduction to the Japanese New Wave Cinema (Bloomington, IN: Indiana University Press, 1988)

Iezumi Hiro, Rika, 'Between Absence and Presence: Exploring Video Earth's What is Photography?' Invisible Culture, 15 (2010), 79-101

Iizawa, Kōtaro, 'The Evolution of Postwar Photography', in The History of Japanese Photography, ed. by Anne Wilkes Tucker and others (New Haven, CT: Yale University Press, 2003)

Kinsella, Sharon, Adult Manga: Culture and Power in Contemporary Japanese Society (London: Routledge. 2000)

McLelland, Mark, 'Japan's Original "Gay Boom”, in Popular Culture and Globalization in Japan, ed. by Matthew Allen and Rumi Sakamoto (London: Routledge, 2006)

Moriyama, Daidō, 1965-1970 Nippon Gekijyō [Japan Theatre] (Tokyo: Getsuyosha. 2009)

Said, Edward, Orientalism (London: Penguin, 1978)

Vartanian, Ivan and Kaneko Ryuichi, Japanese Photobooks of the 1960s and '70s (New York: Aperture Foundation, 2009)

Yamagishi, Shōji, A Hunter by Daido Moriyama (Tokyo: Chūō-kōron-sha, 1972) 